\title{
Untreated Childhood Cerebral Astrocytoma
}

National Cancer Institute

\section{Source}

National Cancer Institute. Untreated Childhood Cerebral Astrocytoma. NCI Thesaurus.

Code C115930.

A finding of cerebral astrocytoma in childhood that has not been treated. 